\title{
HELYI ÖNKORMÁNYZATOK HÁLÓZATAINAK SZEREPE A GLOBÁLIS KORMÁNYZÁSBAN
}

\author{
(The Use of Local Government's Networks \\ in the Global Governance)
}

\author{
KOVÁCS LAURA
}

Kulcsszavak:

hálózatosodás helyi önkormányzatok európai érdekérvényesitése EU-önkormányzatok

Megfigyelhetö a városok autonómiájának globális szintéren való folyamatos növekedése. Két fóbb fejlódési irány játszik fontos szerepet ebben a folyamatban: a globalizáció, illetve a decentralizáció. Láthatjuk, hogy a városok újabb és ujabb közvetlen kapcsolatokat, együttmüködéseket hoznak létre globális szervezetekkel, egyre erösebb pozíció alapjait megteremtve a globalis térben. A globális szervezetek pedig szintén keresik a városok együttmüködését, hiszen globális normákat, irányvonalakat sikerül ez által ,lokalizálni”. Európában, ugyanúgy, mint a világ más részein a városok együttmúködéseiböl létrejövő hálózatok száma rendkívïli mértékben növekszik. Néhányuk az Európai Unió döntés-elökészitö folyamatának befolyásolása érdekében alakult, mig más hálózatok az információáramoltatás érdekében jöttek létre, egy adott közpolitikai területre fókuszálva. A tanulmány a fenti jelenségek elméleti hátterét vizsgálja néhány jelentỏsebb hálózat bemutatásával.

\section{Bevezetés}

Tanulmányunkban olyan városi önkormányzatokat tömörítỏ hálózatok rendszerbe foglalására törekszünk, amelyek a hatékony önkormányzati érdekérvényesítés nemzetközi színtéren való megjelenítését tủzik ki célul, különválasztva az európai és egyéb nemzetközi szervezetekben, valamint az uniós színtéren történő önkormányzati érdekérvényesítési lehetőségeket. Az érdekérvényesítés hatékonyságának növelése érdekében a városok között bilaterális, illetve multilaterális kapcsolatok alakulnak, amelyek sok esetben különböző nemzetközi szervezetek, uniós intézmények támogatását élvezik. A hálózatok nemzetközi támogatottságának motivációira szintén kitérünk. Továbbá néhány olyan csatornát mutatunk be, melyek segítségével a döntések kivitelezésének gyakorlati problémájával szembekerülö önkormányzatok előlépnek régióik, illetve országaik árnyékából. Az önkormányzatok hálózatosodásának jelenségét vizsgálva fontosnak tartjuk megemlíteni, hogy a városok hogyan szervezik meg magukat globális színtéren, milyen hatást gyakorolt rájuk az europaizáció. Természetesen a tanulmányban tárgyalt jelentősebb hálózatokon kívül számtalan tematikus hálózat múködik még.

A hálózatosodás jelensége tulajdonképpen a ,governance" struktúra részét képezi. A politikatudományban széles körü szakirodalom tárgyát képezi a hálózatosodás, 
Kovács Laura : Helyi önkormányzatok hálózatainak szerepe a globális kormányzásban.

Tér és Társadalom 24. évf. 2010/1. 103-117. p.

104 Önkormányzatiság

TÉT XXIV. évf. 2010

melyben már elkülönült a közpolitikai hálózatok vizsgálata. Heclo és Widlavsky (1974) amerikai politológusok közös tanulmányukban felhívták a figyelmet a civilek és a politikusok között kialakuló hálózatok fontosságára, továbbá Heclotól (1978) származik az egycélú hálózatok (,issue networks") fogalmának meghatározása is, amely sok nagybefolyású és marginális szereplő laza szerveződését jelenti. A következő áramlat a hálózatosodás tanulmányozásában annak európai trendjeire vonatkozott, amelyben már a kormányzatok közti kapcsolatrendszerek kerültek a vizsgálódás középpontjába. Nagy hangsúlyt kapott az a feltevés, hogy a politikaalkotás és annak kivitelezése számos résztvevő közti komplex együttmúködést, koordinációt és tárgyalásos mechanizmust igénylö folyamat. A hálózatosodás későbbi irányzata a helyi közösség kutatásokból nötte ki magát, melyben föként a politika társadalmi dimenzióinak vizsgálata kapott szerepet (Ansell 2006).

Fent említett megközelítések egyöntetüen kiemelik, hogy a politikai struktúra és folyamat rendkívuil differenciált, a résztvevő́k széles körét foglalja magában, ebböl adódóan a résztvevőknek javasolt összekapcsolódni közös érdekeik mentén, egy adott közpolitikai tárgykörben. Rhodes megkülönbözteti az „egycélú hálózatokat” a „közpolitikai közösségektől", utóbbi a tagság tartós, szoros kapcsolatát, erőteljes integráltságát, vertikális egymásrautaltságát emeli ki. Továbbá a „hatalom-függőség” perspektívájának körülírásával megalapozza az arról való gondolkodás keretét, hogy miért és hogyan alakulnak hálózatok, miképpen müködnek (Ansell 2006).

A városhálózatok intézménye összekapcsolódik a policentrikus gondolkodásmóddal. A városhálózati együittmüködésben a pontszerüen elhelyezkedő városok közötti kapcsolatokon van a hangsúly, az ilyen együttmüködési formákban nincs helye a város és környéke viszonylatnak. A városhálózatok azonban nem csupán városi önkormányzatok, közszereplök együttmüködését jelentik, hanem governance típusú partnerségi kooperációkat takarnak. A szakemberek azonban hangsúlyozzák, hogy célmeghatározó tényezöiknek mindvégig az önkormányzatoknak kell maradniuk (Somlyódyné Pfeil 2008).

\section{A nemzetközi önkormányzati együttmüködés föbb keretei}

\section{Hálózatok globális színtéren}

Megfigyelhető a városok autonómiájának globális színtéren való folyamatos növekedése. Két főbb fejlödési irány játszik fontos szerepet ebben a folyamatban: a globalizáció, illetve a decentralizáció. Láthatjuk, hogy a városok újabb és újabb közvetlen kapcsolatokat, együttmüködéseket hoznak létre globális szervezetekkel, egyre erösebb pozíció alapjait megteremtve a globális térben. A globális szervezetek pedig szintén keresik a városok együttmüködését, hiszen globális normákat, irányvonalakat sikerül ez által „lokalizálni”. Mind a növekvő kölcsönös függőség (gazdasági, kulturális, technológiai), mind pedig a globális fejlődési irányvonal megjelenik helyi szinten, a helyi szint pedig befolyással bír a globalizáció dinamizmusára. 
Saskia Sassen (1991)- nevéhez a globalizáció szakirodalmában elterjedt „világváros” terminus köthetô, - körülírta a világvárosokból álló hálózat létrejöttét. Napjaink globális problémái - környezetszennyezés, szegénység, társadalmi instabilitás - legerösebben a városokban érzékelhetők. „A városok és a különböző települések magukban hordozzák annak lehetőségét, hogy maximalizálják a globalizáció előnyeit, illetve ellensúlyozzák annak negatív hatásait." (Cities in a... 2001, 233)

A decentralizáció az a már említett fejlődési irány, amely közremúködik a városi autonómia globális térben való erősítésében, kiterjesztésében. Az európai és nemzetközi intézmények, valamint számos nemzeti kormány által egyaránt támogatott folyamat. Szintén egy világméretủ trendről van szó, mely közvetlenül elősegíti a városok önállóságának növelését, mind egy adott államon belül, mind pedig nemzetközi viszonylatban (Nijman 2009).

A hálózatok alapja mindig valamiféle közös érdekeltség. A hálózat létrehozói között születhetnek formális megállapodások, és akár egy lobbi csoport jellemzőit is magukra ölthetik. Más kezdeményezések funkcionális érdekeket helyeznek elötérbe. Nem mindegyik hálózat követi az ún. „bottom up”, alulról felfelé történő építkezést. Az Európai Unió Bizottsága például kifejezetten támogatja a hálózatokat, valamint azt, hogy egymással összekapcsolódva vegyenek részt a Közösségi Kezdeményezésekben. A hálózatok megmutatják, hogy a helyi önkormányzatok miként vesznek részt számos müködési területen, folytatnak eszmecserét az európai politikák befolyásolási lehetőségeit keresve.

A városok világszerte jelentős nemzetközi kapcsolatokat építenek ki. A fővárosok kialakították saját nemzetközi kapcsolatokkal vagy külügyekkel foglalkozó intézményeiket. Ezek a hivatalok felelősek a különböző nemzetközi kereskedelmi ügyletek lebonyolításáért, külföldi beruházásokért, nemzetközi együttmüködés megvalósításáért, a város külkapcsolatainak fejlesztéséért, mind globális szervezetekkel (mint például az ENSZ kapcsolódó programjai), mind pedig nem kormányzati és egyéb globális városok közti hálózatokkal. Bilaterális és multilaterális kapcsolatok alakulnak ki a városok között, ide értve a testvérvárosi kapcsolatok hagyományos együttmüködéseit is.

Az ENSZ keretein belül az ENSZ-HABITAT (ENSZ Emberi Települések Központja) az, amely kiemelten a helyi önkormányzás erősítésére törekszik. 1976-ban jött létre a településfejlődés világméretủ problémáinak megoldása, enyhítése céljából a Vancouverben rendezett világkonferencián mint az ENSZ új szakosított szervezete. Létrehozását az urbanizáció világméretú kibontakozása - elsősorban a népességnek a városok felé áramlása, az infrastrukturális hiányosságok, illetve az ezzel együtt járó súlyos feszültségek indokolták, amelyek feloldása nemzetközi összefogást sürgetett. Az új szervezet alapvetổ céljául a világ különbözỏ részein jelentkező településfejlődési problémák feltárását és azok orvoslását jelölték meg. Bizonyos értelemben egyszerre beszélhetünk decentralizációról és lokalizációról az ENSZ filozófiáját illetően, mely a városi önkormányzatok helyzetbehozására törekszik.

Az ENSZ 1992. július 14-én Rio de Janeiróban „Környezet és fejlődés” címmel megtartott konferenciáján elfogadott Agenda 21 lefektette egy globális akcióterv alap- 
Kovács Laura : Helyi önkormányzatok hálózatainak szerepe a globális kormányzásban.

Tér és Társadalom 24. évf. 2010/1. 103-117. p.

106 Önkormányzatiság

TÉT XXIV. évf. 2010

jait a 21. századi fenntartható fejlödés elérése érdekében. Az Agenda 28. fejezete kimondja, hogy a helyi önkormányzatok közremüködése nélkül a fenntartható fejlődés nem valósítható meg. Arra ösztönzi a helyi önkormányzatokat, hogy helyi közösségekkel együttmüködve segítsék elö a fenntartható fejlödés helyi szinten történő megvalósulását. Annak a szuikségletnek a felismerése, hogy valamennyi települési szövetség egységesen, koordinált keretek között lépjen fel, s ez által az ENSZ-et segítő testületként, annak egyenrangú partnereként jelenjen meg a külvilág számára, vezetett a World Assembly of Cities and Local Authorities Coordination (WACLAC) megalapításához. A WACLAC azóta az ENSZ hivatalos tanácsadó szervévé lépett elő azokban az esetekben, amikor a telepuiléseket érintő ügyekről vagy a telepuilések feladatairól van szó. Például jelentős szerepet játszott az AGENDA 21 esetén, amikor a községek nélkül az ENSZ környezetvédelmi célkitüzései nehezen lettek volna a gyakorlatba átültethetők.

Az OECD is nagy figyelmet fordít a hálózatosodás, illetve a partnerség különböző jelenségeinek tanulmányozására. Ennek egyik eredménye, hogy 1999-2003 között az OECD egy mélyreható tanulmányt készített a területi alapú partnerséggel kapcsolatban, amely 14 ország tapasztalatai alapján készült. Az első eredményt 2001-ben publikálták „Helyi partnerség a jobb kormányzásért” címmel. Kimutatták, hogy a partnerség jelentős hatást gyakorolhat a helyi kormányzásra, olyan hosszan, amilyen hosszan a partnerek biztosítani tudják tevékenységük elvégzését (OECD 2001). Az OECD LEED elnevezésủ fórumát a partnerségről és a helyi kormányzásról 2004 szeptemberében hozták létre az ausztriai Szövetségi Gazdasági és Munkaügyi Minisztérium támogatásával. A fórum - az OECD helyi partnerségekről szóló tanulmánya alapján - szaktudáson, valamint kialakult hálózatokon alapul. Lehetőséget teremt a világszerte kialakult partnerségek tapasztalatcseréjére. Napjainkban a fórum 2400 tagot számlál, 45 országból. Bármely olyan intézmény vagy szervezet a tagjává válhat, amely magában foglalja a terület-alapú partnerségi menedzsmentet. A fórum törekvése, hogy optimalizálja a partnerségek és más kormányzási formák közremủködését a helyi gazdaság és foglalkoztatás fejlesztésében, valamint a politikák hatékonyságában. A partnerséget a következőképpen definiálja a fórum: „a területi-alapú partnerség a kormányzás jobbá tételének eszköze". Arra törekszik, hogy javítsa a politikai együttmüködést, valamint adaptálja a helyi viszonyokhoz, célravezetőbbé teszi a programok meghatározását a civil társadalom bevonásával a stratégiai tervezés feladatába a széles körủ részvételi demokrácia által, serkentve ezzel a helyi projektekben való közös részvételt, támogatva a közpolitikák iránti nagyobb elégedettséget (LEED én.).

\section{Egyesült Városok és Helyi Önkormányzatok Világszervezete}

Kiemelkedő szerepet játszik az Egyesült Városok és Helyi Önkormányzatok Világszervezete (UCLG) a helyi önkormányzatok nemzetközi érdekeinek megjelenítésében. 
Kovács Laura : Helyi önkormányzatok hálózatainak szerepe a globális kormányzásban.

Tér és Társadalom 24. évf. 2010/1. 103-117. p.

Legföbb feladatai közé tartozik a tagjai közötti egység és együttműködés megteremtése, politikai reprezentáció nemzetközi színtéren, demokratikus helyi önkormányzás megteremtése, decentralizált együittmüködés, nemzetközi együttmüködés, testvérvárosi, valamint egyéb partnerségi kapcsolatok kialakításának elösegítése helyi önkormányzatok és azok szervezetei között. Támogatja a tagok közt alakuló, egyre erősödő hálózatot szoros együttmüködésben az ENSZ-szel. A fenti célok elérése érdekében konferenciákat szervez, publikációkon keresztül biztosítja az információ áramlását.

\section{Helyi Hatóságok Nemzetközi Egyesülete (IULA)}

A szervezet 1913-as létrehozásával új korszakot nyitott a nemzetközi városi kapcsolatok terén. Formális, szabályozott kapcsolatok alakultak a helyi hatóságok szervezetei között. A szervezet célja, hogy előmozdítsa a demokratikus helyi kormányzatok összekapcsolódását világszerte. Jelenleg hét regionális szekciója van, melyek saját helyi kormányzataikat képezik információs és dokumentációs központokat felállítva, kutatásokat folytatva, projektek építésének képességét elömozdítva, támogatja a törvényhatóságok közti nemzetközi együttmüködést (International Union of Local Authorities).

A Helyi Hatóságok Nemzetközi Egyesülete jelentős kihívás előtt állt Rio de Janeiróban 2001. májusában. Itt született meg ugyanis az Egyesült Városok Szervezetével (UTO) már évek óta kilátásba helyezett együttműködési megállapodás annak érdekében, hogy az ENSZ-szel szemben egy erösebb partner lépjen fel, egy olyan, amelynek tevékenységi köre az egész világra kiterjed, amely a világ valamennyi kontinensének településeit képviseli, és ezáltal ténylegesen esélye van arra, hogy az ENSZ egyenrangú partnerként kezelje (Szabó 2005).

\section{Helyi önkormányzatok európai érdekérvényesítésének lehetöségei}

\section{Az europaizáció városi dimenzioja}

Európában, ugyanúgy, mint a világ más részein a városok együttműködéseiből létrejövő hálózatok száma rendkívüli mértékben növekszik. Néhányuk az Európai Unió döntés-elökészítő folyamatának befolyásolása érdekében alakult, míg más hálózatok az információáramoltatás érdekében jöttek létre, egy adott közpolitikai területre fókuszálva. A városok europaizációjáról beszélve elmondható, hogy rendkívül fontos szerepet töltenek be az EU többszintü kormányzásának struktúrájában. A többszintủ kormányzás megközelítése alapján az EU sokrétü, különböző szintekböl összetevớdö kormányzati rendszer, amely magában foglalja az európai, a nemzeti, valamint a nemzeti szint alatti területeket. Ebből a szempontból a kormányzás színterei nem képezik részét egy hierarchikus berendezkedésnek. Továbbá, ez jelenti azt 
Kovács Laura : Helyi önkormányzatok hálózatainak szerepe a globális kormányzásban.

Tér és Társadalom 24. évf. 2010/1. 103-117. p.

108 Önkormányzatiság

TÉT XXIV. évf. 2010

is, hogy a helyi, nemzeti és nemzetközi intézmények közti kompetenciák elmozdulása nem csupán felfelé irányul az EU irányába, hanem lefelé is, a nemzetállamok, régiók, városok irányába. John Peter szavaival élve az europaizáció a helyi kormányzás egyik legföbb aspektusa (Peter 2000).

\section{Az Európa Tanács jelentősége a helyi önkormányzatok helyzetbehozásában}

Az Európa Tanács alapokmánya 1949. május 5-én került aláírásra Londonban. Az Európa Tanács célja, hogy szervezeti együttmüködést teremtsen azoknak az eszméknek és elveknek a védelme érdekében, amelyek a gazdasági és szociális elörehaladást szolgálják. Tagjait a tagállamok parlamentjei választják, vagy nevezik ki.

Az Európa Tanács szerepe meghatározó volt a helyi és regionális önkormányzatok helyzetbehozásában, Európában. 1994-ben az Európa Tanács tanácsadó szervként létrehozta az Európai Helyi és Regionális Önkormányzatok Kongresszusát (CLRAE), amely az addig müködö Európai Helyi és Regionális Önkormányzatok Állandó Értekezlete helyébe lépett.

\section{Helyi és Regionális Közhatóságok Európai Kongresszusa (CLRAE)}

A Helyi és Regionális Hatóságok Kongresszusa Európában egy, az Európa Tanácson belüli fórum, melynek keretében 41 tagország 291 helyi és regionális politikusa rendszeresen találkozik, hogy a helyi és regionális demokrácia fejlődésével kapcsolatos gyakorlati együttmúködésröl tanácskozzon. A szubnacionális rendszerek sokféleségéből következően a helyi önkormányzati rendszerek eltérö típusainak érdekellentéte intézményi téren a regionális szint különválását, a helyi önkormányzati képviselőktől való elszakadását jelentette. Így a CLRAE-nek helyi és regionális kamarája is van. Székhelye Strasbourgban található. Az intézmény általános célja, hogy elősegítse a helyi és regionális demokrácia fejlödését. Gyakorlati aspektusok felvázolásával segíti a tagállamokat a helyi demokrácia hatékony megteremtésében. Biztosítja, hogy a tagállamok a Helyhatóságok Európai Chartájában elfogadott normáknak megfeleljenek. Célcsoportját az Európa Tanács tagállamaiban tevékenykedő helyi és regionális választott képviselök alkotják. Minden tevékenysége beleértve az ENTO-t ${ }^{1}$ és az ADACS- ${ }^{2}$ is - a helyi demokrácia megerősítését célozza. A CLRAE együttmüködik a Régiók Bizottságával (CoR) a két intézmény közt létrejött megegyezés alapján, figyelemmel kíséri a regionális és helyi demokrácia alakulását az EU-hoz csatlakozni kívánó országokban (Congress of Local and Regional Authorities).

A magyar CLRAE delegáció tagjait az országos önkormányzati szövetségek javaslatára az önkormányzatokért felelős miniszter delegálja. Legutóbb 2008-ban újultak meg a delegációk az Európa Tanács mind a 47 tagállamából, lakosságszámarányosan meghatározva azok létszámát, így hazánkból 7 állandó és 7 helyettes tag 
Kovács Laura : Helyi önkormányzatok hálózatainak szerepe a globális kormányzásban.

Tér és Társadalom 24. évf. 2010/1. 103-117. p.

TÉT XXIV. évf. 2010 a 1

Önkormányzatiság

109

képviselheti a különböző szintủ önkormányzatokat a Helyi Önkormányzatok Kamarájában és a Régiós Kamarában.

Az Európa Tanács az 1985-ben közzétett dokumentumával, a Helyi Önkormányzatok Európai Chartájával egy igazi sikertörténetet írt, leszögezi, hogy a helyi önkormányzatok a demokrácia alappilléreit jelentik. A charta a törvényhozási reform mintájául szolgál az új demokráciákban, a benne foglalt elveket egyes országok alkotmányukba is beillesztették. Az Európa Tanács 47 tagállamából 44 ratifikálta, köztük az EU 27 tagállama. A charta az önkormányzatok politikai, közigazgatási és pénzügyi függetlenségét ajánlja, természetesen az ehhez szükséges szabályozás kialakítását a tagállamokra bízza. Az EU tagjelölt államinak feltétlenül támogatniuk kell a Helyi Önkormányzatok Európai Chartájának ratifikációját.

\section{Európai Telepuilések és Régiók Tanácsa (CEMR)}

Az Európai Települések és Régiók Tanácsa (Council of European Municipalities and Regions) mintegy 100 ezer helyi és regionális önkormányzatot tömörító szervezet. Megalakításától, 1951-tő̉l kezdve célja biztosítani az önkormányzatok intézményes képviseletét a Közösségi Szerződések által kitűzött célok megvalósításában. A CEMR egy európai együttmúködés megvalósítására törekszik a regionális és helyi önkormányzatok között, amely lehetővé teszi a közös álláspont kialakítását valamennyi, a regionális és helyi önkormányzatok tevékenységére hatással bíró közösségi ügyben. Az Európai Települések és Régiók Tanácsa a Régiók Bizottságának legfontosabb lobbi szervezete, sok közös képviselö tevékenykedik mindkét szervezetben. A CEMR együttmúködik más európai önkormányzati szervezetekkel és hálózatokkal annak érdekében, hogy közös politikai platformok és állásfoglalások jöhessenek létre (Council of European Municipalities and Regions). Magyarországról két bejelentett tagszervezet tevékenykedik az Európai Települések és Régiók Tanácsában, a Települési Önkormányzatok Országos Szövetsége és a Kisvárosi Önkormányzatok Országos Érdekvédelmi Szövetsége.

A CEMR Fehér Könyvében a következőt emeli ki: az európai kormányzás magában foglalja a különböző kormányzati és nem kormányzati szintek közti kapcsolatok teljes hálózatát. Ennek következtében bármely rendszer, amely hálózatot kíván kialakítani a hatékonyság, az átláthatóság érdekében, támaszkodhat a demokratikus kormányzatokból összetevődő többszintủ kormányzás intézményére. Elmondható, hogy az európai regionális és helyi önkormányzatok többsége már hálózatokba szerveződött, akár földrajzi elhelyezkedésük, akár gazdasági, kulturális jellemzőik alapján, melyek összeköttetést biztosítanak számukra az Unió intézményeivel. Az Unión belül az egységes helyi önkormányzati szint hiánya ellenére, az európai ügyekben való közös fellépés igénylésének eredménye a határokon átnyúló, nemzetközi hálózatok kialakulása, melyek célja, hogy intenzívebbé tegyék a tapasztalatcserét, valamint a közös érdekek kifejezésre juttatása (CoR 2001). 
Kovács Laura : Helyi önkormányzatok hálózatainak szerepe a globális kormányzásban.

Tér és Társadalom 24. évf. 2010/1. 103-117. p.

110 Önkormányzatiság

TÉT XXIV. évf. 2010 a 1

\section{Eurocities}

Az Eurocities elődje a hat városból álló ún. „második városok” kezdeményezés (az elnevezés a fỏváros utáni második városra utal, a nemzeti hierarchiában). Ebben a következő városok vettek részt: Barcelona, Birmingham, Frankfurt, Lyon, Milánó és Rotterdam. Az 1986-ban, Rotterdamban megrendezésre került „Városok, mint a gazdasági növekedés hajtóeröi" címü konferencia idejére ezek a városok már számos testvérvárosi megállapodással rendelkeztek. Így elhatározták, hogy kialakítanak egy hálózatot az EU-val kapcsolatos tevékenységeik koordinálására, az információáramlás biztosítására. 1991-ben a városok forrásokhoz jutottak az EU Recite Programból (Régiók és városok Európában), továbbá ugyanebben az évben egy formális hálózat létrehozása mellett döntöttek, melynek az Eurocities elnevezést adták egy birminghami találkozó alkalmával. A szervezet önálló irodát nyitott Brüsszelben, hogy megkönnyítse a városok közötti szaktudás- és tapasztalatcserét, kapcsolatot alakítson ki az Európai Unió intézményeivel. Az irodát 1992-ben nyitották meg, nem sokkal ezután csatlakoztak az újabb tagok. Az Eurocities nemzetközi szervezet, melyben külön nemzeti szekciók kialakítására nem került sor. A szervezet fỏ elve a városok közvetlen részvétele a hálózat tevékenységében. Tagsága folyamatosan növekszik, 2006-ra a tag-városok száma már elérte a 120-at (HeineltNiederhafner 2008).

Két feltétele van annak, hogy egy város az Eurocities tagjává válhasson, az egyik, hogy 250 ezer fö feletti lakosságszámmal rendelkezzen, a másik pedig a demokratikus választáson alapuló kormányzati struktúra. Bár tagjai közt találhatunk nem tagállami városokat is, a szervezet tevékenysége egyértelmủen az EU politikákra koncentrál.

Minden tag-város egyetlen szavazattal rendelkezik az éves találkozón, mely minden novemberben megrendezésre kerül. Ez az Eurocities legföbb szerve, mely tagjai közül választja az Adminisztratív Bizottságot, valamint az elnököt. Az elnök feladata a találkozók lebonyolítása, a szervezet képviseletének ellátása. Az Eurocities keretei között a következő bizottságok müködnek a tagok érdeklődésének megfelelően: Kulturális Bizottság, Gazdaságfejlesztési és Városmegújítási Bizottság, Kelet-Nyugat Bizottság, Környezeti Bizottság, Szociális Bizottság, Közlekedési Bizottság, Technológiapolitikai Fórum. Továbbá munkacsoportok is felállításra kerültek, melyek kisebbek a tematikus bizottságoknál (www.eurocities.eu).

Az Eurocities az interakció ún. „top-down” módozatát alkalmazza, azáltal, hogy tájékoztatja tagjait az EU politikákról, a brüsszeli iroda döntés-elökészítö tevékenységét látja el, mely szoros kapcsolatban áll az EU intézményeivel, és ellenőrzi azok releváns városi ügyekkel kapcsolatos tevékenységét. A brüsszeli iroda, valamint a tagok közti információ-áramoltatás elektronikusan is megoldott (HeineltNiederhafner 2008).

Az Eurocities egy ún. Network-je a Tele Citys, amelyben a tagsághoz a település méretét tekintve semmilyen korlátozás nincs. Abban nem csak települések, hanem különböző szakmai vagy érdekvédelmi szövetségek is részt vehetnek. Az érdekvé- 
Kovács Laura : Helyi önkormányzatok hálózatainak szerepe a globális kormányzásban.

Tér és Társadalom 24. évf. 2010/1. 103-117. p.

TÉT XXIV. évf. 2010 『 1

Önkormányzatiság

111

delmi szervezet keretében megfogalmazásra került az ún. Európai eJogok Kartája, melynek legjelentősebb mérföldkövei a következők:

- Követelményrendszert szab az önkormányzatok részére, hogy az információáramlás és a tudástársadalom létrehozása érdekében milyen szolgáltatásokat, milyen jogokat, milyen képzést és milyen támogatást kell nyújtani a polgárok számára.

- Összeállításra került egy „,best practices” gyűjtemény, amely nemzetközi síkon ismertté és hasznosíthatóvá próbálja tenni az önkormányzati megoldásokat (www.eurocities.eu).

\section{Eurotown}

A közepes méretủ városok hálózata 1991-ben jött létre. Az 50 ezer-250 ezer fös lakossággal rendelkező városok együttmúködését támogatja. A közös társadalmi, gazdasági, környezeti változások tekintetében az Eurotown a hálózat tagjainak érdekérvényesítését segíti, továbbá elömozdítja köztiùk az információcserét, hozzájárul új projektek kialakításához, potenciális partnerek felkutatásához (www.eurotowns.org).

\section{Helyi önkormányzatok az Európai Unióban}

Az Európai Unió és az önkormányzatok kapcsolódása viszonylag új keletủ jelenség a közösség történetében. A helyi önkormányzatok bekapcsolódását a Strukturális Alapok 1988-as reformja tette lehetővé, és így a regionális és ennek hiányában a helyi önkormányzatok is részévé váltak a döntéshozatalnak. Elöször ekkor alakulhatott ki kapcsolat uniós bizottság és regionális vagy helyi hatóság között. A helyi és regionális szint integrálódása eltérő attól függően, hogy milyen az adott ország adminisztratív rendszere, illetve, hogy milyen külkapcsolati jogosultsággal bírnak az önkormányzatok (Hervainé Szabó 1998).

Az 1980-90-es évek döntései jelentősen megváltoztatták az Európai Unió intézményi felépítését. Az Egységes Európai Okmány (1986), az Európai Unióról szóló Szerződés (1992) és az Amszterdami Szerződés (1997) az Unió nemzetközi környezetében bekövetkezett változások eredményeképpen születtek meg. Az integráció folyamata megerősítette az EU intézményeit a tagállamok szuverenitásának rovására (Soós 2002).

Az Unió maga is érdekelt abban, hogy hivatalosan is szerephez jussanak a regionális és helyi kormányzati szintek a döntéshozatalban, illetve részt vegyenek a jogalkotásban. Szerintünk ez három okkal magyarázható:

1) Az EU hatáskörének bővítése, illetve hatékonyságának növelése folytán egyre több uniós politika megvalósítása került regionális, illetve helyi szintre. 
2) A második ok főként az arányosság elvéből adódik, de szerepet játszik a hatékonyság és a szubszidiaritás elve is, mivel azok az extra erőforrások, amelyeket a regionális és a helyi szint használ, az uniós politikai döntések eredményei.

3) Végül a harmadik ok az EU demokratikusabbá tételének céljából adódik, bár mindegyik célkitüzéssel összefüggésbe hozható. A polgárokhoz való közelség, ez az a terület, ahol a helyi és regionális szinteknek módjában áll növelni a részvételt az EU döntés-előkészítő folyamatában, a tagállamok polgárainak segítségével. Így lehet hatékonyabb az Unió, adminisztratív és politikai értelemben egyaránt (Regional and local... 2001).

A helyi önkormányzatok szervezetére és múködésére vonatkozó európai közösségi jogszabályok, elö́rások nincsenek. A helyi önkormányzatok azonban több vonatkozásban is érintettek az uniós elvárások helyi végrehajtása, illetve végrehajtatása során. A széles feladat- és hatáskörükbooll adódóan a közösségi jogszabályok közvetve, illetve közvetlenül befolyásolják és meghatározzák a helyi önkormányzatok tevékenységét azáltal, hogy az önkormányzati szabályozás hatáskörébe tartozó teriileteken jogharmonizációs kötelezettséget keletkeztethetnek, vagy önkormányzati hatáskörbe tartozó feladatok ellátására vonatkozó kötelező érvényủ elöírásokat tartalmazhatnak (Soós 2002).

\section{Régiók Bizottsága (CoR)}

Az intézmény tagjai többnyire polgármesterek, önkormányzati, tartományi vezetők, de kizárólag olyan személyek, akiket közvetlenül, demokratikusan választottak meg. Tagjainak száma jelenleg 344. A nemzeti delegációk összetételének kialakítása a tagállamok kompetenciája. Legföképpen helyi önkormányzatok képviseltetik magukat a szervezetben, hiszen a kisebb EU tagállamok, mint például Írország, Dánia és Észtország, nem rendelkeznek regionális önkormányzatokkal. A szervezet konzultatív jellegéből adódóan hatásköre korlátozott. Az alapító szerződések értelmében a Bizottság és a Tanács köteles konzultálni a Régiók Bizottságával olyan javaslatok tárgyalásakor, amelyek érintik a helyi, illetve a regionális önkormányzatokat. A Maastrichti Szerződés öt ilyen területet jelölt meg (gazdasági és társadalmi kohézió, transz-európai infrastruktúra hálozatok, egészség, oktatás, kultúra), melyeket az Amsterdami Szerződés még öttel kiegészített (foglalkoztatáspolitika, társadalompolitika, környezetvédelem, szakképzés, közlekedés) (Kern 2009).

A Lisszaboni Szerződés a helyi és a regionális dimenziót az EU jogi keretébe emeli, és kimondja, hogy az Uniónak tiszteletben kell tartania a tagállamok nemzeti identitását, mely elválaszthatatlan része azok alapvető politikai és alkotmányos berendezkedésének, ideértve a regionális és helyi önkormányzatokat is. A szerzödés egyszerủen csak racionalizálja az Unió és a tagállamok közötti hatáskörmegosztást azáltal, hogy meghatározza, kinek mi a feladata. Ennek következtében csökken azoknak a homályos pontoknak a száma, melyek zavart vagy bizonytalanságot eredményezhetnek a jövőben (Lisszaboni Szerződés... 2007). 
Kovács Laura : Helyi önkormányzatok hálózatainak szerepe a globális kormányzásban.

Tér és Társadalom 24. évf. 2010/1. 103-117. p.

TÉT XXIV. évf. 2010 - 1

Önkormányzatiság

113

Nálunk az önkormányzati szövetségek vezetői és a regionális fejlesztési tanácsok jelöltek tagokat a Régiók Bizottságába. Említésre méltó az a tény, hogy az önkormányzati szövetségek által delegált képviselök mandátuma e testiiletben közvetett.

A magyar delegáció vezetője szerint a Régiók Bizottságában nem annyira egy-egy régió, hanem inkább az ország érdekében lehet lobbizni. Nagyon fontos, hogy az adott helyi vagy országos érdekeket közösségi érdekként lehessen bemutatni, hiszen különben nehéz más nemzeti delegáltakat az adott ügy támogatására megnyerni. A Régiók Bizottságába delegáltak felvetették, hogy sajnálatosan kevés befolyása van ennek az intézménynek. Gondot okoz számukra az is, hogy nem tudnak megfelelỏ szakmai bázisra támaszkodni egyik régióban sem. A regionális érdekérvényesítést nehezíti, hogy a CoR tagjai politikai pártcsoporthoz tartozás alapján is megosztottak, nemcsak szakmai bizottságokban végzik munkájukat és fogadnak el állásfoglalásokat, illetve érzékelhető ellentét is megfigyelhetố a különböző szintek (régió-kistérség-önkormányzat) képviselői között (Laczkóné Tuka 2008).

A Régiók Bizottságának elnöksége „Együttmüködés a regionális és helyi hatóságokat képviselö európai szövetségekkel" tárgyban 2002. május 14-én hozott határozatában felhatalmazta a fótitkárt, hogy különbözỏ önkormányzati érdekszövetségekkel való egyuittműködés megerősítését célzó intézkedéseket hozzon. Ez az együttműködés jelenleg rendszerezett keretek között folyik, melyet a CoR főtitkára és a szövetségek fötitkárai között évente háromszor rendezett találkozók révén figyelemmel kísérnek ( $C o R$ 2007). A Régiók Bizottsága és a jelentősebb európai szövetségek közötti együttmúködési szándék gyakorlati formát öltött a strukturált párbeszéd, a szövetségek elnökeinek vagy képviselöinek a CoR szemináriumain és konferenciáin való részvétele és felszólalása, az Open Days, a CoR elnökének a legfontosabb európai szövetségek éves közgyülésein való részvétele, valamint az öszszes jelentős európai szövetség együttmüködésével kidolgozott közös cselekvési tervek kiadása által. 2009-ben az alábbi szervezetekkel készülttek közös cselekvési tervek: AEBR, AER, CALRE, CEMR, CPMR, Eurocities, REGLEG, CPMR, ArcoLatino (www.cor.europa.eu).

\section{Az önkormányzatok és az EU föbb szerveinek kapcsolódási pontjai}

A következőkben arra keressük a választ, hogy milyen szerepet kapnak a helyi önkormányzatok az EU többszintủ kormányzati rendszerében, döntéshozatalában, valamint, hogyan kapcsolódnak az EU fö szerveihez: a Bizottsághoz, az Európai Unió Tanácsához és az Európai Parlamenthez.

A Tanácshoz füződô közvetlen kapcsolatok kialakítása nem könnyủ a helyi önkormányzatok számára, az intézmény speciális jellege miatt. A Tanács egy kisebb brüsszeli adminisztratív apparátuson kívül a tagállamok kormányaiból tevődik össze, teljesítve az alapító szerződések által meghatározott feladatokat, mely magában foglalja a tagállamok különböző törekvéseinek összehangolását, szem előtt tartva a közös célokat, a tagállamok képviseletét, valamint a nemzeti érdekek megóvását. Mivel a 
nemzeti érdekek dominálnak a Tanácsban, rendkívuil fontos, hogy a tagállami képviseletek jól ismerjék a különböző nemzeti és hazai érdekeket. A városokkal és szervezeteikkel való kapcsolattartás e tekintetben válik kiemelkedően fontossá.

A Bizottság központi szereplő az EU törvényhozási folyamatában, egyrészt a törvénykezdeményezési jogosultsága miatt, másrészt a törvényjavaslatok kidolgozásának felelőssége miatt. A javaslatok kidolgozása rendkívül nagy szakértelmet igényel. A városok és az őket képviselő szervezetek kiemelkedő szerepet játszanak a Bizottság informálásában. A helyi önkormányzatok szervezeteinek nemzetközi, európai szintéren megvalósuló érdekartikulációja legitimációt biztosít, növeli a Bizottság kezdeményezéseinek elfogadottságát. A legitimáció minőségét tekintve a helyi önkormányzatok és szervezeteik különböznek más érdekcsoportoktól. A választott kormányzati testuiletek közelebb állnak az állampolgárokhoz, így képesek megjeleníteni a tág értelemben vett polgárság érdekeit. Rendkívül fontos szerepet töltenek be a városok az EU szabályozás kivitelezésében is. Nem csak azzal vannak tisztában, mi tekinthetö politikailag, társadalmilag elfogadhatónak, hanem azzal is, mi az, ami technikailag valóban kivitelezhető a különbözö célok, programok vonatkozásában. A Bizottság 2004-ben bevezette a helyi önkormányzatok intézményeivel való rendszeres párbeszédet, ezáltal lehetőséget teremtve, hogy véleményt mondjanak az Unió politikáival kapcsolatban (Heinelt-Niederhafner 2008).

A Bizottság aktívan közremúködik a ,governance” hálózatos formáinak terjedésében Európa-szerte. Az Unión belül elcsúszó kompetenciák, együttesen annak többszintủ karakterével, vezettek az EU politikák hálózatainak burjánzásához a különböző szakpolitikák területén. A Bizottság egy csomópont ezen hálózatok mủködésében, mivel számos szereplő közötti interakció bemeneti csatornája. A Bizottság politikai hálózatokat támogató szerepe javaslat-előkészítő, illetve EU programokat menedzselö feladatából adódik. E folyamat részeként dolgozta ki a Bizottság a Közösségi Kezdeményezéseket, amelyek nagymértékben járultak hozzá a transznacionális, inter-regionális, valamint a helyi együttmüködések létrejöttéhez, terjedéséhez (Bovaid et al. 2002).

Az Európai Parlament közösségi jogszabályalkotásban játszott szerepe folyamatosan növekszik. Ahhoz, hogy e funkcióját megfelelően el tudja látni, a Parlament tagjainak információra van szüksége, amelyet sok esetben a városok, illetve az azokat képviselö szervezetek szolgáltatnak (Heinelt-Niederhafner 2008).

Az Europai Parlament ma már a közösségi politikák egy jelentős részénél igen erőteljes befolyással bír, hiszen vagy a Tanáccsal egyenrangú, vele együtt döntő szerv, vagy hozzájárulását kell adnia egy, a Tanácsban tárgyalt döntéshez. Mindezen esetekben a Parlament gyakorlatilag vétójoggal bír, azaz nélküle az Európai Unió nem tud döntéseket elfogadni, jogszabályokat alkotni. Az Európai Parlament elsősorban azokon a területeken kapott ilyen erős beleszólást, amelyek vagy közvetlenül az állampolgárok jogait, érdekeit, vagy az EU lényegét jelentő belsỏ piac müködését érintik (www.europarl.europa.eu).

Fontos szerveződések alakulnak az EP-n belül, ilyenek például az ún. Intergroup-ok, melyeknek számos támogatója van; köztük is megtaláljuk a városok képviseleteit. Az EP képviselö-jelöltek kiválasztása a nemzeti pártok hatáskörében van. Annak ellené- 
Kovács Laura : Helyi önkormányzatok hálózatainak szerepe a globális kormányzásban.

Tér és Társadalom 24. évf. 2010/1. 103-117. p.

re, hogy az EP tulajdonképpen a pártok „terepe”, mégis különböző szervezetek széles spektruma határozza meg, ideértve a nemzetek feletti és a helyi szereplőket egyaránt.

Ezekre a kapcsolatokra szükségük van az Európai Parlament tagjainak ahhoz, hogy megfelelően ellássák európai szintủ feladataikat. Különösen azokban az esetekben, amikor a városok vagy szervezeteik megpróbálnak hatást gyakorolni a különböző szereplőkre az EU többszintủ rendszerének különböző szintjein. Ezen keresztül befolyásolhatják egy adott jogszabály javaslat keresztuilvitelét, esetleg akadályozhatják azt, nyilvános diskurzust ébreszthetnek. A városok jelentősek az EP tagok számára, hiszen kapcsolatot teremtenek a választóikkal, információval szolgálnak a hazai politikai ügyekkel kapcsolatban, ezáltal az EP tagjai valamilyen szinten függetlenedni tudnak nemzeti párt-politizálástól, amely hozzásegíti öket a megfelelö feladatellátáshoz EU szinten (Heinelt-Niederhafner 2008).

\section{Összegzés}

Az általunk feldolgozott szakirodalom alapján elmondható, hogy az európai integráció városokra gyakorolt hatásáról még mindig az a legelterjedtebb nézet, mely szerint ez veszélyt jelent a helyi autonómiára nézve, hiszen a helyi önkormányzatok valósítják meg az EU jogszabályok nagy részét, mégis korlátozott befolyásuk van az Unió döntéshozatalára.

Összességében elmondható, hogy a városok európai szervezetei különleges kollektív szereplök, mert a közérdeket jelenítik meg, és valódi kapcsolódási pontokkal kötődnek az állampolgárokhoz. A helyi önkormányzatok pozíciója az Európai Unió intézményrendszerén belül még mindig gyengének mondható, de időről-időre megerősödik, ilyen periódus volt például a Régiók Bizottságának létrehozása, valamint az Alkotmányszerzödés körül zajló vita idöszaka. Az államok belső struktúrája határozza meg, hogy a helyi önkormányzatok hivatalosan milyen módon képviseltetik magukat Brüsszelben. A föderális államokban lévő regionális önkormányzatok erős pozíciója miatt (pl. Nêmetország) a helyi önkormányzatok gyengébbek a centralizált országok helyi önkormányzatainál (pl. Írországban).

Az EU-ban az önkormányzatok érdekképviseletét megvalósító Régiók Bizottságának, munkája hatékonyságának érdekében, jogosultságai bővítésére lenne szükség, amelyre sajnos kevés az esély a közeljövőben, hiszen a Lisszaboni Szerződés is csak apróbb változtatásokat tartalmaz a szervezetre vonatkozóan.

A hálózatosodás elismerten előfeltétele a döntés-előkészítő mechanizmusok demokratikusabbá, átláthatóbbá, hatékonyabbá tételének, melynek során a helyi önkormányzatok kapcsolatokat építhetnek az uniós intézményekkel. Az viszont, hogy uniós szinten is megfelelỏen tudják érdekeiket érvényesíteni a hálózat tagjai, feltételezi az államokon belül megfelelöen müködő hálózatok meglétét is, azaz, a kormányzat-régió-helyi szint vonatkozásában, illetve más társadalmi, gazdasági szereplók bevonásával. 
Mind az uniós intézmények, mind egyéb nemzetközi szervezetek (ENSZ, OECD) részéről megfogalmazódott a helyi önkormányzatok nemzetközi színtéren való erőteljesebb érdekérvényesítésének segítése. Véleményünk szerint e törekvések határozottabb összehangolására lenne szükség. Érdemes lenne foglalkozni annak lehetőségével, hogy a különböző hálózatok közti aktívabb információáramlás megvalósuljon, bár már nem ritka jelenség, hogy ugyanaz a képviselö párhuzamosan tevékenykedik több szervezetben, továbbá számos példa akad az önkormányzati szervezetek együttmüködésére.

Az önkormányzatok nemzetközi képviseletét megvalósító intézményekben nem minden esetben megoldott a helyi, illetve a regionális kamara különválasztása, ami véleményünk szerint bizonyos esetekben nézetkülönbségek forrása lehet.

A hálózatok megközelítésének vonatkozásában fontos kiemelni az önkormányzatok egyenlötlen adminisztratív, pénzügyi kiindulópontját. Ebből következően rendkívül különbözőek a képességeik, lehetőségeik a kormányzás szerkezetének fejlesztésére, mely szükséges lenne bizonyos projektek kivitelezéséhez. Hazánk számára is tanulságos, hogy a megfelelő nemzetközi szintủ érdekérvényesítéshez erősebb jogkörökkel rendelkezö, nagyobb pénzügyi önállósággal bíró önkormányzatokra lenne szükség. A magyarországi önkormányzati érdekszövetségek sokkal hatékonyabb érdekképviselet megvalósítására lehetnének képesek mind a hazai, mind pedig nemzetközi színtéren. Ennek érdekében összehangoltabb munkára, jobb információáramlásra, valamint jelentősebb mértékủ anyagi források biztosítására lenne szükség. Ezen kívül több figyelmet kellene fordítani a professzionális szakemberek képzésére. További hiányosságnak tartjuk, hogy az Unió ,átláthatóság” alapelve csak részben teljesül az önkormányzatok nemzetközi képviseletét illetően. Az azonban elmondható, hogy az önkormányzatok összehangolt cselekvése nyomán lehetővé vált, hogy nagyobb önállósággal szervezzék külkapcsolataikat, a legtöbb önkormányzat már hazánkban is rendelkezik külkapcsolatokkal foglalkozó bizottsággal. Mindemellett a brüsszeli lobbi hálózatok kiépítése is folyamatosan növekszik.

Láthattuk, hogy az önkormányzatok közti hálózatok kialakulása nemzeti és nemzetközi szinten egyaránt támogatott jelenség. A hálózatokban való részvételük egy dinamikus tanulási folyamat, mely ösztönzöleg hat a kormányzás új formái felé való elmozdulásukra. A rendkívül különböző célok, értékek mentén kialakuló hálózatok megkönnyítik tagjaik érdekérvényesítési lehetőségeit, elősegítik közös céljaik megvalósulását, az eddiginél hatékonyabb problémamegoldást jelentenek jelenlegi formájukban is, bár a nemzetközi színtéren történö önkormányzati érdekérvényesítés lehetőségei hagynak kívánnivalót maguk után, mind a hatékonyságot, a koordinációt, mind pedig a megfelelő nemzetközi jogi hátteret illetően. 
Kovács Laura : Helyi önkormányzatok hálózatainak szerepe a globális kormányzásban.

Tér és Társadalom 24. évf. 2010/1. 103-117. p.

TÉT XXIV.évf. 2010 — 1

Önkormányzatiság

117

\section{Jegyzetek}

${ }^{1}$ A helyi és regionális hatóságok oktató szervezetének európai hálózata. Segíti és koordinálja az együttmüködést a helyi és regionális oktató központok között. Kapcsolatot teremt a nemzeti szervezetek és külfföldi partnereik között.

${ }^{2}$ Speciális program, a helyi és regionális demokráciák támogatására jött létre az európai országokban. Prioritást ad a helyhatósági törvénykezés, rendeletalkotás, helyi pénzügyek segítésének. A program segíti a határon átnyứló együittmủködést Közép- és Kelet-Európa országaiban.

\section{Irodalom}

Ansell, Ch. (2006) Network Institutionalism. - Binder, S.-Rhodes, R.-Rockman, B. (eds.) Oxford Handbook of Political Institutions. Oxford University Press, Oxford. 76-89. o.

Bovaird, T.-Löffler, E.-Parrado-Díez, S. (2002) Developing Local Governance Networks in Europe. Nomos Verlagsgessellschaft, Baden-Baden.

CoR (2001) Report by working group on "multi-level governance": linking and networking the various regional and local levels. Group 4c. http://ec.europa.eu/governance/areas/groups10/report_en.pdf

CoR (2007) A Régiók Bizottsága elnökségének 102. ülése: Együttmüködés az európai regionális és helyi szövetségekkel. Régiók Bizottsága, Brüsszel.

Hervainé Szabó Gy. (1998) Az Európai Unió - államok - régiók - önkormányzatok viszony fejlödése. Csefkó F. (szerk.) EU-Integráció. Önkormányzatok I. Magyar Önkormányzati Szövetségek Társulása, Budapest. 105-126. o.

Heinelt, H.-Niederhafner, S. (2008) "Cities and Organised interest intermediation in the EU Multi-Level System." - European Urban and Regional Studies. 2. 173-187. o.

Kern, K. (2009) Cities in a European setting. Conference: Innovation for good local and regional governance. April 2-3. Enschende, the Netherlands.

Laczkóné Tuka Â. (2008) Regionális identitás - nemzetközi nyomás a kialakítására?! A dunántúli régió képviselete Brüsszelben. - Európai Tükör. 11. 107-122. o.

LEED (én.) Forum on Partnership and Local Governance. http://www.oecd.org/document /22/0,3343,en_2649_34455_20743766_1_1_1_1,00.html

Lisszaboni Szerződés az Európai Unióról szóló szerződés és az Európai Közösséget létrehozó szerződés módosításáról. (2007) - EUR-Lex. 50. évf. C306/1. http://eur-lex.europa.eu

Nijman, J.E. (2009) Cities in a global setting: the growing autonomy of cities in the global legal order. Conference: Innovation for good local and regional governance. April 2-3. Enschende, the Netherlands.

OECD (2001) Local Partnership for Better Governance. OECD, Paris. http://www.oecd.org/document/ 59/0,3343,en_2649_34455_33834555_1_1_1_1,00.html

Peter, J.(2000) „The europeanisation of sub-national governance.” - Urban Studies. 5-6. 877-894. o.

Regional and Local Government in the European Union. Responsibilities and Resources. (2001) CdR studies. Office for Official Publicationsof the European Communities, Brussels. 19-25. o.

Somlyódyné Pfeil E. (2008) A városi térségek a közigazgatási struktúra és a „governance" keresztmetszetében. - Tér és Társadalom. 1. 27-43. o.

Soós E. (1999) Integráció és Regionalizmus. Bába és Társai Kiadó, Szeged.

Soós E. (2002) Az önkormányzatok és az európai unió kohéziós politikája. Biztonságpolitikai Központ, Szeged. http://www.scsp.hu/test/head/edu/c8/10_hu.htm

Szabó A. (2005) A Helyi Önkormányzatok Európai Chartájának és az ENSZ Helyi Önkormányzati Világ-chartájának kapcsolódási pontjai. - Collega. 2. 64 69. o. 